\title{
Are baby foods as innocent as they may look?
}

\author{
C.J. Geraghty ${ }^{1}$, S. Taleghani ${ }^{1}$, S. O’Mahony ${ }^{1}$, O.C. Lyons ${ }^{1,2}$, C.M. Donovan ${ }^{1}$, \\ C.B. O'Donovan ${ }^{1}$ and M.A.T. Flynn ${ }^{1,2}$ \\ ${ }^{1}$ Food Safety Authority of Ireland, Dublin, Republic of Ireland and ${ }^{2}$ Nutrition Innovation Centre for Food and Health, \\ Ulster University, Coleraine, BT52 1SA, UK
}

Guidelines for best infant feeding practice in Ireland recommend that foods given during the first year of life should be plain, with minimal added sugar, fat or salt ${ }^{(1)}$. A 2011 survey of commercially available baby foods (targeting infants $<12$ months) found that $15 \%$ were inappropriate due to levels of added fat, sugar or salt and a lack of essential nutrients ${ }^{(2)}$. The aim of this study was to examine 'baby foods' marketed in Ireland in 2017 and assess if market trends are more in line with best practice recommendations, compared with baby foods available in 2011.

A comprehensive survey of commercially available baby foods marketed in Ireland was conducted between August and November 2017, using methods similar to those of the 2011 survey $^{(2)}$. Data collected included product name, brand, targeted age group (months), meal type, portion size, presence of gluten and nutritional information per $100 \mathrm{~g}$. In addition, the presence of nutrition and health claims and saturated fat content was collected in 2017. Baby foods primarily based on cereal, milk or fruit were deemed appropriate. All other baby foods were compared, in terms of their fat, saturated fat and sugar content, with best versions (e.g. reduced fat or sugar) of adult foods. Baby foods that matched adult foods which are not recommended for healthy eating (e.g. biscuits, crisps) were categorised as inappropriate. All baby foods were classified into meal types and compared with those available in 2011 in terms of their nutritional content (see table below).

\begin{tabular}{|c|c|c|c|c|c|c|c|c|c|c|}
\hline \multirow{2}{*}{ Per $100 \mathrm{~g}$} & \multicolumn{2}{|c|}{ Energy (kcals) } & \multicolumn{2}{|c|}{ Fat $(\mathrm{g})$} & \multicolumn{2}{|c|}{ Sugar $(\mathrm{g})$} & \multicolumn{2}{|c|}{ Fibre $(\mathrm{g})$} & \multicolumn{2}{|c|}{ Salt (g) } \\
\hline & 2011 & 2017 & 2011 & 2017 & 2011 & 2017 & 2011 & 2017 & 2011 & 2017 \\
\hline Breakfast & $\begin{array}{l}135 \\
(64-427)\end{array}$ & $\begin{array}{l}394 * * \\
(54-500)\end{array}$ & $\begin{array}{l}3 \cdot 1 \\
(0-14)\end{array}$ & $\begin{array}{l}5 \cdot 3 \\
(0-46)\end{array}$ & $\begin{array}{l}11 \cdot 2 \\
(0-48)\end{array}$ & $\begin{array}{l}19 \cdot 0 \\
(0-46)\end{array}$ & $\begin{array}{l}1.4 \\
(0-11)\end{array}$ & $\begin{array}{l}2 \cdot 5^{*} \\
(0-12)\end{array}$ & $\begin{array}{l}0 \cdot 1 \\
(0-0 \cdot 4)\end{array}$ & $\begin{array}{l}0 \cdot 0 \\
(0-0 \cdot 7)\end{array}$ \\
\hline Lunch/Dinner & $\begin{array}{l}66 \\
(27-418)\end{array}$ & $\begin{array}{l}63^{* *} \\
(26-416)\end{array}$ & $\begin{array}{l}2 \cdot 0 \\
(0-13)\end{array}$ & $\begin{array}{l}1.9 * * \\
(0-8)\end{array}$ & $\begin{array}{l}2 \cdot 1 \\
(0-11)\end{array}$ & $\begin{array}{l}2 \cdot 4^{*} \\
(0-12)\end{array}$ & $\begin{array}{l}1.4 \\
(0-8)\end{array}$ & $\begin{array}{l}1 \cdot 6^{* *} \\
(0-8)\end{array}$ & $\begin{array}{l}0 \cdot 1 \\
(0-2 \cdot 3)\end{array}$ & $\begin{array}{l}0 \cdot 1 * * \\
(0-1)\end{array}$ \\
\hline Dessert & $\begin{array}{l}68 \\
(44-433)\end{array}$ & $\begin{array}{l}66 \\
(41-435)\end{array}$ & $\begin{array}{l}0 \cdot 6 \\
(0-12)\end{array}$ & $\begin{array}{l}0 \cdot 5 \\
(0-12)\end{array}$ & $\begin{array}{l}10 \cdot 7 \\
(3-42)\end{array}$ & $\begin{array}{l}10 \cdot 2^{*} \\
(0-37)\end{array}$ & $\begin{array}{l}1 \cdot 3 \\
(0-6)\end{array}$ & $\begin{array}{l}1 \cdot 7 * * \\
(0-8)\end{array}$ & $\begin{array}{l}0 \cdot 1 \\
(0-0 \cdot 3)\end{array}$ & $\begin{array}{l}0.0 * * \\
(0-0 \cdot 3)\end{array}$ \\
\hline Snack & $\begin{array}{l}74 \\
(44-457)\end{array}$ & $\begin{array}{l}80 \\
(41-532)\end{array}$ & $\begin{array}{l}1 \cdot 2 \\
(0-16)\end{array}$ & $\begin{array}{l}1 \cdot 1 \\
(0-29)\end{array}$ & $\begin{array}{l}11 \cdot 7 \\
(0-43)\end{array}$ & $\begin{array}{l}10 \cdot 6 \\
(0-46)\end{array}$ & $\begin{array}{l}1 \cdot 8 \\
(0-7)\end{array}$ & $\begin{array}{l}1 \cdot 8^{*} \\
(0-17)\end{array}$ & $\begin{array}{l}0 \cdot 1 \\
(0-1)\end{array}$ & $\begin{array}{l}0 * * \\
(0-1 \cdot 5)\end{array}$ \\
\hline Drink & $\begin{array}{l}32 \\
(11-280)\end{array}$ & $\begin{array}{l}19 * * \\
(8-23)\end{array}$ & $\begin{array}{l}0 \cdot 1 \\
(0-7)\end{array}$ & $\begin{array}{l}0 \cdot 2 \\
(0-0)\end{array}$ & $\begin{array}{l}7 \cdot 7 \\
(2-69)\end{array}$ & $\begin{array}{l}4 \cdot 1 * * \\
(1-5)\end{array}$ & $\begin{array}{l}0 \\
(0-1)\end{array}$ & $\begin{array}{l}0^{*} \\
(0-0)\end{array}$ & $\begin{array}{l}0 \cdot 1 \\
(0-0 \cdot 3)\end{array}$ & $\begin{array}{l}0 \\
(0-0)\end{array}$ \\
\hline
\end{tabular}

Values are presented as Median (Minimum-Maximum). The differences between baby foods available in 2011 and 2017 were assessed using Mann-Whitney U Test where significance is denoted as $* \mathrm{p}<0 \cdot 05, * * \mathrm{p}<0 \cdot 01$

In 2017, 481 baby foods were identified compared with 441 in 2011. As shown in table above, there was an overall tendency for baby foods to be significantly lower in salt and have a reduced sugar content, particularly drinks. In 2017 compared with 2011 , a $74 \%$ reduction in drinks $(\mathrm{p}<0.001)$ and a $72 \%$ increase in the number of snacks $(\mathrm{p}<0.001)$ was observed. Among snacks $(n 174)$, the majority $(74 \%)$ were assessed as inappropriate mainly due to the large number of biscuits $(n 15)$ and crisps (n19) available. The majority $(76 \%)$ of baby crisps were found to be higher in saturated fat compared with adult 'reduced fat' crisps, while $67 \%$ of baby biscuits were higher in sugar than plain digestive biscuits. In 2017 vs. 2011, a significantly higher proportion of baby foods available on the Irish market were deemed to be inappropriate $(25 \% \mathrm{vs} .15 \%)$. A $51 \%$ increase in the number of breakfast cereals was observed in 2017 vs. 2011 - almost half (48\%), were deemed to be inappropriate due to high levels of added sugar. The proportions of appropriate and inappropriate baby foods bearing claims were comparable.

While some improvements in baby foods marketed in Ireland in 2017 compared with 2011 were evident (e.g. reduced salt, higher fibre), there was an overall increase in baby foods deemed to be inappropriate. The increasing trend of sugary breakfast cereals and inappropriate snacks (e.g. crisps and biscuits) available as baby foods is worrying. This study informs work at EU level revising legislation regulating baby foods. Parents and caregivers need guidance when choosing baby foods, as some may not be as innocent as they look.

1. Food Safety Authority of Ireland (2012) Best Practice for Infant Feeding in Ireland. Dublin: Food Safety Authority of Ireland; Available from https://www.fsai.ie/publications_infant_feeding/ (Accessed $3^{\text {rd }}$ October 2017)

2. Bennett A, O’Connor A, Flynn MAT et al. (2012) Irish Medical Journal 105, 266-268. 